\title{
THE INFLUENCE OF BENZYLADENINE ON THE FLOWERING OF LIATRIS SPICATA L. 'ALBA' CULTIVATED FOR CUT FLOWERS IN AN UNHEATED PLASTIC TUNNEL AND IN THE FIELD
}

\author{
Elżbieta Pogroszewska, Patrycja Sadkowska
}

\author{
Institute of Ornamental Plants and Architecture of Landscape, University of Life Sciences in Lublin \\ Leszczyńskiego 58, 20-068 Lublin, Poland \\ e-mail: epogroszewska@autograf.pl
}

Received: 3.10.2007

S u m m a r y

The study focused on the influence of benzyladenine (BA) on the flowering of Liatris spicata L. 'Alba' cultivated for two years in an unheated plastic tunnel and in the field. Benzyladenine at a concentration of $0,100,200,400 \mathrm{mg} \times \mathrm{dm}^{-3}$ was applied on the leaf twice during both years of the experiment. It was noted that cultivation of Liatris spicata L.'Alba' in an unheated plastic tunnel leads to the growth of longer inflorescence stems with a bigger fresh weight and a larger number of primary shoots. However, in comparison with control plants, it decreases the yield of inflorescence stems in the first and second year of the plants' flowering. It is beneficial to apply benzyladenine at a concentration of $400 \mathrm{mg} \times \mathrm{dm}^{-3}$ on the leaves of Liatris spicata L. 'Alba' cultivated in an unheated plastic tunnel, because this treatment increases the number and fresh weight of inflorescence stems as well as the number of primary shoots in the first and second year of the plants' flowering. It is also justified to apply benzyladenine at a concentration of $400 \mathrm{mg} \times \mathrm{dm}^{-3}$ on Liatris spicata L. 'Alba' cultivated in the field, as it leads to a greater number and fresh weight of inflorescence stems in the first and second year of flowering.

Key words: Liatris spicata, benzyladenine, unheated plastic tunnel, flowering

\section{INTRODUCTION}

Liatris spicata is a valuable ornamental plant. It grows long, straight and stiff inflorescence stems: 50 $-120 \mathrm{~cm}$ long. On the stems there are flowers gathered into baskets which form a dark pink, purple-red, violet, ivory or white spiky inflorescence. The baskets comprise of narrow ligulate flowers which make them look fluffy. Liatris spicata bears flowers in an untypical way - from the top down to the bottom. Flowering lasts from July until the end of summer.
Liatris spicata is a constantly underestimated plant, but it is certainly worth a greater interest and attention. It is used in flower beds, where it integrates well with other plants. It can also be cultivated for cut flowers. In bouquets it looks impressive in flower compositions as the main flower but also as the secondary decoration.

Traditionally, Liatris spicata is cultivated in the field. In order to obtain earlier flowering, flowers of better quality, and bigger yield, there have been numerous attempts to cultivate it under a covering, predominantly in unheated plastic tunnel (H e t m a n and P o gros ze w s ka, 1997).

In order to obtain greater yield and better quality of inflorescence stems, the unheated plastic tunnel is successfully used to cultivate several species of ornamental plants (Hetman and Pogros zewska, 1995; 1995a; 1996; 1996a; P o g ro s z e w s k a, 1998; Wr a g a, 1999; J a n ow s k a, 2000; S z c z e p a n i a k, 2000).

Ornamental plants' flowering and growth can also be influenced by means of growth regulators. Application of benzyladenine in some plants stimulates the development of side buds, which enhances their decorative value (Pogroszewska and Frączek, 2000; P obudkiewicz, 2005). Increasing the number of shoots, benzyladenine increases the size of plants such as for example Hosta (G a r n e r et al., 1997; K e e v e r and B r a s s , 1998; K o tań s k i et al. 2005). And it can be involved in the flower bud initiation process ( $\mathrm{Gr} \mathrm{z} \mathrm{e} \mathrm{-}$ sik and Rudni cki, 1989; Łuk a s zew ska, 1991; Davi es et al. 1996; S u h, 1997; P obudki ew ic z, 2006). BA affects flowers' morphological features (Kawa-Miszczak et al. 1992; Saniewski et al. 1997).

The aim of the experiment was to study the influence of benzyladenine (BA), applied in various concentrations, on flowering of Liatris spicata L. cultivated in an unheated plastic tunnel and in the field. 


\section{MATERIALS AND METHODS}

The research was conducted in 2004 and 2005. Liatris spicata plants were planted on $8^{\text {th }}$ October, 2003 in local soil in an unheated plastic tunnel and in the field, in $1.5 \mathrm{~m}$ wide patches and in three rows with a distance of $0.40 \times 0.48 \mathrm{~m}$. The research was conducted in the first and second year of the plants' flowering.

Benzladenine (BA) was used at a concentration of: 0, 100, 200 and $400 \mathrm{mg} \times \mathrm{dm}^{-3}$. Preparations were applied on the leaf twice and control plants were sprayed with distilled water. The first treatment was given once the plants reached the height of 16-22 cm (using $40 \mathrm{ml}$ of solution/plant) and the second one when the plants were about $40 \mathrm{~cm}$ high (using $60 \mathrm{ml}$ of solution/plant).

Observations and measurement of the number and length of inflorescence stems, their fresh weight and the number of primary shoots were carried out during the whole experiment process.

The experiment was set up in the system of random block in 3 replicates, where a plot with 6 plants served as a replicate. The results were analyzed statistically by means of variance analysis for double classifications, evaluating the significance of differences by means of Turkey's confidence intervals at the level of significance of $\alpha=0.05$.

\section{RESULTS}

A significant difference in the number of inflorescence stems was noted in the first year of Liatris spicata flowering, depending on the cultivation place (Table 1). The plants cultivated in the unheated plastic tunnel grew $19.8 \%$ of inflorescence stems less than the plants in the field. The plants cultivated in the field and treated with benzyladenine at a concentration of 200 and 400 $m g \times \mathrm{dm}^{-3}$ produced inflorescence yield that was $11.7 \%$ $\left(\mathrm{BA}-200{\mathrm{mg} \times \mathrm{dm}^{-3}}^{-}\right)$and $17.3 \%\left(\mathrm{BA}-400 \mathrm{mg} \times \mathrm{dm}^{-3}\right)$ higher than the yield of the control plants (not treated with the substance). The plants cultivated in the plastic tunnel and treated with BA at a concentration of 400 mg $\times \mathrm{dm}^{-3}$ produced inflorescence yield significantly higher than the control (by 19.4\%)

The inflorescence stems of the plants cultivated in the unheated plastic tunnel in the $1^{\text {st }}$ year of the study were $10.4 \%$ longer than the stems of the plants cultivated in the field (Tab. 1). The plants cultivated in the plastic tunnel and treated with benzyladenine at a concentration of $400 \mathrm{mg} \times \mathrm{dm}^{-3}$ produced inflorescence stems $18.4 \%$ shorter than the control plants. It was observed that the plants cultivated in the tunnel had the tendency to produce shorter inflorescence stems, the bigger the concentration of benzyladenine was.

In the 1st year of flowering, the plants cultivated in an unheated plastic tunnel produced stems with greater fresh weight than that of the plants cultivated in the field (Tab. 1). The difference was 19.4\%. In all the tested concentrations, the bioregulator significantly differentiated the fresh weight of Liatris spicata cultivated in the tunnel. Benzyladenine at a concentration of 400 $\mathrm{mg} \times \mathrm{dm}^{-3}$ proved to be most desirable, as it also had a positive effect on fresh weight of stems in the field, leading to value growth of the tested feature by $48 \%$ and $31.4 \%$ compared to the control plants.

The inflorescence stems of Liatris spicata cultivated in the plastic tunnel in the $1^{\text {st }}$ year of flowering produced 1.5 times more primary shoots than the plants cultivated in the field (Tab. 1). Interaction of the studied factors was marked by the greatest number of primary shoots in the plants growing in the tunnel and treated with the substance at a concentration of $400 \mathrm{mg} \times \mathrm{dm}^{3}$. There were nearly 3 times more of them than in the control plants. In the field, however, BA did not affect branching of Liatris spicata stems.

The age of the plants clearly influenced the yield of Liatris spicata inflorescences. The yield in the unheated plastic tunnel in the $2^{\text {nd }}$ year of flowering was $107.3 \%$ greater than in the $1^{\text {st }}$ year. In the field, it was $94.6 \%$ greater than in the first year.

In the 2 nd year of flowering, the Liatris spicata plants cultivated in the plastic tunnel produced inflorescence yield $14.6 \%$ smaller than the yield of the plants cultivated in the field (Tab. 1). The plants treated with $\mathrm{BA}$ at all the concentrations, both in the field and in the tunnel, produced more inflorescence stems than the control plants. The greatest yield of inflorescence stems was obtained by the application of benzyladenine at a con-

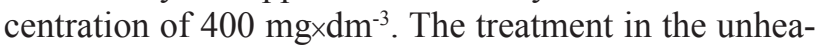
ted plastic tunnel increased yield by $112.3 \%$, whereas in the field by $77.2 \%$ compared to the control plants.

It was observed in the 2 nd year of Liatris spicata flowering that the plants cultivated in the unheated plastic tunnel produced inflorescence stems $14.4 \%$ longer than the plants cultivated in the field. A significant effect of benzyladenine on the length of inflorescence stems of Liatris spicata in the $2^{\text {nd }}$ year of flowering was observed after the application of BA $-400{\mathrm{mg} \times \mathrm{dm}^{-3}}^{-3}$ to the plants in the field. This treatment led to shortening of inflorescence stems length by $8.7 \%$ in comparison to the control plants.

The inflorescence stems of Liatris spicata cultivated in the unheated plastic tunnel in the second year of flowering differed significantly in the fresh weight from the stems of the plants cultivated in the field (Tab. 1). Those plants which grew in the plastic tunnel produced an inflorescence that had fresh weight $17 \%$ higher than the weight of an inflorescence of the plants cultivated in the field.

The plants cultivated in the unheated plastic tunnel and treated with BA at all the concentrations produced inflorescence stems with greater fresh weight than that of the control plants. Inflorescence stems with the greatest fresh weight were obtained from the plants 
Table 1

The effect of benzyladenine on morphological features of inflorescence stems of Liatris spicata L. 'Alba'.

\begin{tabular}{|c|c|c|c|c|}
\hline \multirow{3}{*}{$\begin{array}{l}\text { BA concentration } \\
\left(\mathrm{mg} \times \mathrm{dm}^{-3}\right)\end{array}$} & \multicolumn{4}{|c|}{ Number of inflorescence stems } \\
\hline & \multicolumn{2}{|c|}{ 1st year of flowering } & \multicolumn{2}{|c|}{ 2nd year of flowering } \\
\hline & field & tunnel & field & tunnel \\
\hline $\begin{array}{c}0 \\
100 \\
200 \\
400\end{array}$ & $\begin{array}{l}17.9 \mathrm{~b}^{*} \\
16.2 \mathrm{bc} \\
20.0 \mathrm{a} \\
21.0 \mathrm{a}\end{array}$ & $\begin{array}{l}14.4 \mathrm{~cd} \\
13.0 \mathrm{~d} \\
15.7 \mathrm{bc} \\
17.2 \mathrm{~b}\end{array}$ & $\begin{array}{l}25.5 \mathrm{~d} \\
33.6 \mathrm{c} \\
41.6 \mathrm{~b} \\
45.2 \mathrm{a}\end{array}$ & $\begin{array}{l}20.3 \mathrm{e} \\
25.5 \mathrm{~d} \\
35.6 \mathrm{c} \\
43.1 \mathrm{ab}\end{array}$ \\
\hline Mean & $18.7 \mathrm{~A}$ & $15.0 \mathrm{~B}$ & $36.4 \mathrm{~A}$ & $31.1 \mathrm{~B}$ \\
\hline \multirow{3}{*}{$\begin{array}{l}\text { BA concentration } \\
\left(\mathrm{mg} \times \mathrm{dm}^{-3}\right)\end{array}$} & \multicolumn{4}{|c|}{ Length of inflorescence stems $(\mathrm{cm})$} \\
\hline & \multicolumn{2}{|c|}{1 st year of flowering } & \multicolumn{2}{|c|}{ 2nd year of flowering } \\
\hline & field & tunnel & field & tunnel \\
\hline $\begin{array}{c}0 \\
100 \\
200 \\
400\end{array}$ & $\begin{array}{l}62.0 \mathrm{bc} \\
58.5 \mathrm{c} \\
58.6 \mathrm{c} \\
59.5 \mathrm{c}\end{array}$ & $\begin{array}{l}69.4 \mathrm{a} \\
67.0 \mathrm{ab} \\
66.7 \mathrm{ab} \\
58.6 \mathrm{c}\end{array}$ & $\begin{array}{l}62.1 \mathrm{bc} \\
60.0 \mathrm{~cd} \\
59.8 \mathrm{~cd} \\
56.7 \mathrm{~d}\end{array}$ & $\begin{array}{l}70.0 \mathrm{a} \\
69.0 \mathrm{a} \\
68.2 \mathrm{a} \\
65.7 \mathrm{ab}\end{array}$ \\
\hline Mean & $59.6 \mathrm{~B}$ & $65.8 \mathrm{~A}$ & $59.5 \mathrm{~B}$ & $68.1 \mathrm{~A}$ \\
\hline \multirow{3}{*}{$\begin{array}{l}\text { BA concentration } \\
\left(\mathrm{mg} \times \mathrm{dm}^{-3}\right)\end{array}$} & \multicolumn{4}{|c|}{ Fresh weight of inflorescence stems (g) } \\
\hline & \multicolumn{2}{|c|}{1 st year of flowering } & \multicolumn{2}{|c|}{ 2nd year of flowering } \\
\hline & field & tunnel & field & tunnel \\
\hline $\begin{array}{c}0 \\
100 \\
200 \\
400\end{array}$ & $\begin{array}{l}36.6 \mathrm{c} \\
39.5 \mathrm{c} \\
41.1 \mathrm{bc} \\
48.1 \mathrm{ab}\end{array}$ & $\begin{array}{l}38.3 \mathrm{c} \\
56.0 \mathrm{a} \\
49.5 \mathrm{a} \\
56.7 \mathrm{a}\end{array}$ & $\begin{array}{l}35.1 \mathrm{c} \\
37.6 \mathrm{c} \\
39.4 \mathrm{bc} \\
46.0 \mathrm{ab}\end{array}$ & $\begin{array}{l}37.3 \mathrm{c} \\
45.6 \mathrm{ab} \\
51.9 \mathrm{a} \\
52.5 \mathrm{a}\end{array}$ \\
\hline Mean & $41.2 \mathrm{~B}$ & $49.2 \mathrm{~A}$ & $39.4 \mathrm{~B}$ & $46.1 \mathrm{~A}$ \\
\hline \multirow{3}{*}{$\begin{array}{l}\text { BA concentration } \\
\left(\mathrm{mg} \times \mathrm{dm}^{-3}\right)\end{array}$} & \multicolumn{4}{|c|}{ Number of primary shoots } \\
\hline & \multicolumn{2}{|c|}{ 1st year of flowering } & \multicolumn{2}{|c|}{ 2nd year of flowering } \\
\hline & field & tunnel & field & tunnel \\
\hline $\begin{array}{c}0 \\
100 \\
200 \\
400\end{array}$ & $\begin{array}{l}1.2 \mathrm{~b} \\
2.2 \mathrm{~b} \\
3.5 \mathrm{ab} \\
2.4 \mathrm{~b}\end{array}$ & $\begin{array}{l}2.2 \mathrm{~b} \\
4.2 \mathrm{ab} \\
2.6 \mathrm{ab} \\
6.4 \mathrm{a}\end{array}$ & $\begin{array}{l}1.0 \mathrm{~b} \\
1.8 \mathrm{~b} \\
1.8 \mathrm{~b} \\
3.2 \mathrm{ab}\end{array}$ & $\begin{array}{l}1.8 \mathrm{~b} \\
2.0 \mathrm{ab} \\
3.8 \mathrm{ab} \\
5.9 \mathrm{a}\end{array}$ \\
\hline Mean & $2.6 \mathrm{~B}$ & $4.1 \mathrm{~A}$ & $2.2 \mathrm{~B}$ & $3.6 \mathrm{~A}$ \\
\hline
\end{tabular}

* Means followed by the same letters are not significantly different at $\alpha=0.05$ level of probability. Means of each year were compared separately. 
sprayed with benzyladenine at a concentration of 400 $\mathrm{mg} \times \mathrm{dm}^{-3}$. Those stems had $40.7 \%$ greater fresh weight than the weight of stems produced by the control plants. The plants cultivated in the field and treated with benzyladenine at a concentration of $400 \mathrm{mg} \mathrm{dm}^{-3}$ produced inflorescence stems with fresh weight $31.0 \%$ greater than the weight of the control plants' stems.

In the 2nd year of cultivation, the Liatris spicata plants cultivated in the plastic tunnel produced $63.6 \%$ more primary shoots than the plants in the field (Tab. 1). Interaction of the studied factors was marked with the greatest number of primary shoots in the Liatris spicata plants growing in the unheated plastic tunnel and treated with BA $-400 \mathrm{mg} \times \mathrm{dm}^{-3}$. There were over 3 times more of them than in the control plants.

\section{DISCUSSION}

This experiment shows that plants cultivated in an unheated plastic tunnel produce a smaller yield than plants cultivated in the open field, which confirms the results obtained by $\mathrm{Hetman}$ and Pogroszew s k a (1996) who claimed that cultivation in a plastic tunnel decreases the yield of Liatris spicata. Similar effects were observed by P o gros ze w s k a and S a d k ow k a (2006) in a research on Astilbe $x$ arendsii Arends. Depending on the species, plants can react differently to cultivation in an unheated plastic tunnel. Pogroszewska's research (1998) on Iris sibiri$c a$ and Hetman and Pogroszewska's research (1996) on flowering of Helleborus $x$ hybridus hort. prove that cultivation in an unheated plastic tunnel increases plants' yield. Similar results were obtained by J a now ska (2000) and Janows ka and S chroeter (2001). The authors claimed that the inflorescence yield of Dianthus barbatus cultivated in a tunnel was greater than the yield of plants cultivated in the field. These observations are also confirmed by Puczel and Wa ź b ińs k a (2003) in the research on Craspedia globosa, and by Wraga (1999) in the research on Molucella laevis $\mathrm{L}$.

In the experiment, the inflorescence of Liatris spicata cultivated in a plastic tunnel had better quality, as estimated by the length and fresh weight of inflorescence stems than stems from field cultivation. This confirms the results of research on Liatris spicata by Hetman and P o gros zew s ka (1997). A similar reaction to cultivation in an unheated plastic tunnel is observed in case of: Iris sibirica (P o g r o s z e w s k a, 1998), Molucella laevis L. (W r a g a, 1999) and Astilbe $x$ arendsii Arends (P o g r o s z e w s k a and S a d k o w $\mathrm{ska}, 2006)$. However, based on the research on Erigeron hybridus Bergm. 'Dunkelste', S z c z e p a n i a k (2000) informs that despite rich flowering, the plants in a plastic tunnel produced inflorescence stems of poor quality.
In our own research, the application of benzyladenine increased the number of inflorescence stems produced by Liatris spicata. A similar positive effect of benzyladenine on plants' flowering was noted by B o y le (1995) in the research on Easter cactus 'Crimson Giant' and by L e e et al. (1999) in experiments on Oncidium.

The plants of Liatris spicata treated with benzyladenine at a concentration of $400 \mathrm{mg} \cdot \mathrm{dm}^{-3}$ produced inflorescence stems with a greater number of primary shoots than the control plants. A similar reaction of plants to benzyladenine was noted by B e s s 1 e r (1997), who obtained a greater number of side branching due to benzyladenine in Tillandsia, and by $\mathrm{Pobudkiewicz}$ (2005), who showed that the application of BA on the leaf improves growth of Dianthus caryophyllus L. of Colorado Majestic Mountain group. Results obtained in our own research are not consistent with the results of research by Wang and B o o g h e r (1987) on Syngonium podophyllum Schott. 'White Butterfly', in which even the concentration of $2000 \mathrm{mgxdm}^{-3}$ did not have a positive effect on this feature.

In all the studies conducted, the plants treated with benzyladenine at a concentration of $400 \mathrm{mg} \times \mathrm{dm}^{3}$ produced shorter inflorescence stems than the control plants. Similarly, Ki m and Okubo (1996) inform about the shortening of Lablab purpureus stems, in comparison to the control, under the influence of benzyladenine. Analogical results were obtained by K i m et al. (2000) in the research on Doritaenopsis 'Happy Valentine' and by P obudki e wi c z (2005) in the research on pot carnation.

\section{CONCLUSIONS}

1. Cultivation of Liatris spicata L.'Alba' in an unheated plastic tunnel leads to the growth of longer inflorescence stems with a bigger fresh weight and a larger number of primary shoots. However, in comparison with control plants, it decreases the yield of inflorescence stems in the first and second year of plant flowering.

2. It is beneficial to apply benzyladenine at a concentration of $400 \mathrm{mg} \times \mathrm{dm}^{-3}$ on leaves of Liatris spicata cultivated in an unheated plastic tunnel, because this treatment increases the number and fresh weight of inflorescence stems as well as the number of primary shoots in the first and second year of plant flowering.

3 . It is also justified to apply benzyladenine at a concentration of $400 \mathrm{mg} \times \mathrm{dm}^{-3}$ on Liatris spicata cultivated in the field, as it leads to a greater number and fresh weight of inflorescence stems in the first and second year of flowering. 


\section{REFERENCES}

Bessler B., 1997. The use of 6-benzylaminopurine for rapid multiplication of tillandsias. Hort. Sci. 32 (2): 256-258.

Boyle T. H., 1995. BA influences flowering and dry-matter partitioning in shoots of 'Crimson Giant' Easter cactus. Hort. Sci. 30 (2): 289-291.

Davies L. J., Hicklenton P. R., Catley J. L., 1996. Vernalization and growth regulator effects on flowering of Gypsophila paniculata L. cvs Bristol Fairy and Bridal Veil. J. Hort. Sci. 71 (1): 1-9.

Grzesik M., Rudnicki R. M., 1989. The influence of growth regulators on growth and the branching of budded roses. Prace Inst. Sad. i Kwiac. ser. B, 13: 113-117.

Garner J. M., Keever G. J., Eakes D. J., Kessler J. R., 1997. Benzyladenine-induced offset formation in Hosta dependent on cultivar. Hort. Sci. 32 (1): 91-93.

Hetman J., Pogroszewska E., 1995. Schedule of yielding of 8 varieties of Paeonia lactiflora in four years of cultivation in a plastic tunnel without heating. Mat. V Ogólnopolskiego Zjazdu Hodowców Roślin Ogrodniczych, Skierniewice 22-24.02.1995: 494-500 (in Polish).

Hetman J., Pogroszewska E., 1995a. Possibilities of flowering acceleration of Helleborus niger in an unheated plastic tunnel. Materiały X Ogólnopolskiego Zjazdu Kwiaciarzy, Skierniewice 21-22 września 1995: 32-33 (in Polish).

Hetman J., Pogroszewska E., 1996. Accelerated cultivation of Helleborus $x$ hybridus hort. in an unheated plastic tunnel and in the field. Materiały XI Ogólnopolskiego Zjazdu Kwiaciarzy, Skierniewice 16-17 maja 1996: 43 (in Polish).

Hetman J., Pogroszewska E., 1996a. Comparison of flowering of polish cultivars of peonia (Paeonia lactiflora) in an unheated plastic tunnel and in a field. Zesz. Nauk. ATR Bydg. Ser. Rol. 197 (39): 87-98 (in Polish).

Hetman J., Pogroszewska E., 1997. Flowering of Liatris spicata cultivated under unheated foil tunnel and in the field with mulching application. Zesz. Probl. Post. Nauk Rol. 449: 61-74 (in Polish).

Janowska B., 2000. The cultivation of Dianthus barbatus L. in unheated plastic tunnel. Rocz. AR Pozn. CCCVIII, Ogrodn. 29: 61-64 (in Polish).

Janowska B., Schroeter A., 2001. The yielding of Dianthus barbatus L. grown in the field and in an unheated plastic tunnel. Zeszyty Naukowe Akad. Roln. im. H. Kołłątaja w Krakowie, 379: 99-103 (in Polish).

Kawa-Miszczak L., Węgrzynowicz E., Saniewski M., 1992. The effect of removal of roots and aplication of plant growth regulators of tulips shoot growth. Acta Hort. 325: 71-76.

Keever G. J., Brass T. J., 1998. Offset increase in Hosta following benzyladenine application. J. Environ. Hort. 16 (1): 1-3.

Kim S. E., Okubo H., 1996. Hormonal control of growth habit in determinate lablab bean (Lablab purpureus). Scientia Hortic. 65: 95-104.
Kim T. J., Lee C. H., Paek K. Y., 2000. Effects of growth regulators under low temperature environment on growth and flowering of Doritaenopsis 'Happy Valentine' during summer. J. Korean Soc. Hort. Sci. 41 (1): 101-104.

Kotański E., Witomska M., Łukaszewska A., 2005. Intensification of Hosta sp. production. Zesz. Probl. Post. Nauk Rol. 504: 645-649 (in Polish).

Lee J. S., Park B. M., Park H. B., 1999. Effects of GA, BA, zeatin and kinetin on flowering of Oncidium 'Aloha'. Korean J. Hort. Sci. Techn. 17 (2): 134-135.

Łukaszewska A., 1991. Growth regulators in the cultivation of roses. Ogrodnictwo, 4: 22-23 (in Polish).

Pobudkiewicz A., 2005. The influence of BA on branching of pot carnation. Zesz. Probl. Post. Nauk Rol. 504: 209-214 (in Polish).

Pobudkiewicz A., 2006. Stimulation of pot plants branching by means of cytokinin. Postępy Nauk Rolniczych, 2: 4352 (in Polish).

Pogroszewska E., 1998. Accelerated cultivation of siberian iris (Iris sibirica L.) in an unheated plastic tunnel. Fol. Univ. Agric. Stetin. Agricultura, 187 (70): 95-105 (in Polish).

Pogroszewska E., Frączek A., 2000. Induction of Strelitzia (Strelitzia reginae Banks) branching. Roczniki Akademii Rolniczej w Poznaniu CCCXVIII, 29: 85-89 (in Polish).

Pogroszewska E., Sadkowska P., 2006. The influence of gibberellic acid on the flowering of Astilbe $x$ arendsii Arends 'Amethyst' cultivated for cut flowers in unheated plastic tunnel and in the field. Zesz. Probl. Post. Nauk Rol. 510: 497-505 (in Polish).

Puczel U., Waźbińska J., 2003. Influence of the method of cultivation and date of sowing on the yield of Craspedia globosa Benth. Zesz. Probl. Post. Nauk Rol. 491: 217222 (in Polish).

Saniewski M., Mynett K., Puchalski J., 1997. Formation of parrot-like flowers after treatment of non-parrot tulip bulbs with benzyladenine before flower bud development. Acta Hort. 430: 107-115.

Suh J. K., 1997. Stem elongation and flowering response of Tulipa cultivars as influenced by bulb cooling. Growth regulators and light quality. Acta Hort. 430: 101-106.

Szczepaniak S., 2000. The height and quality of yield of Erigeron hybridus Bergm. and Delphinium x cultorum Voss in an unheated plastic tunnel. Rocz. AR Pozn. CCCXXIII, Ogrodn. 31, cz. 1: 171-175 (in Polish).

Wang Y. T., Boogher C. A., 1987. Effect of stock plant shading, developmental stage and cytokinin on growth and lateral branching of Syngonium podophyllum Schott. 'White Butterfly'. Scientia Hortic. 33: 137-145.

Wraga K., 1999. Influence of cultivation site on the yield of Molucella laevis L. plant material. Materiały VIII Ogólnopolskiego Zjazdu Naukowego „Hodowla Roślin Ogrodniczych u progu XXI wieku”, AR Lublin: 381-384 (in Polish). 


\section{Wpływ benzyloadeniny na kwitnienie liatry kłosowej (Liatris spicata L.) 'Alba' uprawianej na kwiat cięty w nieogrzewanym tunelu foliowym i w polu}

\section{Streszczenie}

Zbadano wpływ benzyloadeniny (BA) na kwitnienie liatry kłosowej (Liatris spicata L.) 'Alba' uprawianej przez dwa lata $\mathrm{w}$ nieogrzewanym tunelu foliowym i w gruncie. Benzyloadeninę w stężeniach: 0, 100,

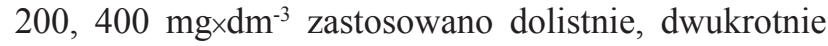
w obu latach trwania doświadczenia. Stwierdzono, że uprawa liatry kłosowej w nieogrzewanym tunelu foliowym sprzyja wytwarzaniu dłuższych pędów kwiato- stanowych, o większej świeżej masie i większej liczbie rozgałęzień I-rzędu, ale zmniejsza plon pędów kwiatostanowych w pierwszym i w drugim roku kwitnienia roślin, w porównaniu do roślin kontrolnych. Korzystne jest dolistne stosowanie benzyloadeniny w stężeniu 400 mg $\times \mathrm{dm}^{-3}$ na rośliny liatry kłosowej uprawianej w nieogrzewanym tunelu foliowym, gdyż zabieg ten zwiększa liczbę i świeżą masę pędów kwiatostanowych oraz liczbę rozgałęzień I-rzędu w pierwszym i w drugim roku kwitnienia roślin. Celowe jest stosowanie benzy-

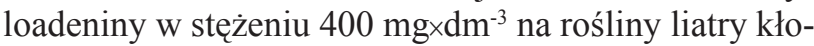
sowej uprawianej w polu, ze względu na większą liczbę i świeżą masę pędów kwiatostanowych w pierwszym i drugim roku kwitnienia. 